\title{
The Deaf Literacy (DEAFLI): A European Project for Young and Adult Deaf People E-learning
}

\author{
Natalia Pérez Aguado and Maria del Pilar Fernández-Viader \\ Departament de Psicologia Evolutiva i de l'Educació, Universitat de Barcelona, Barcelona, España
}

\begin{abstract}
DEAFLI is a GRUNDTVIG project (538750-LLP-1-2013-1-ES) thought to help deaf people improve their language skills and their chances to access employment. DEAFLI is a 10-lesson course designed to enhance the acquisition of key competences in written language by young deaf people and deaf adults. DEAFLI aims to improve their education and to facilitate their access to the labour market in the countries taking part in the project (Spain, Austria, Italy and the UK), therefore, materials and resources will be developed for this purpose. DEAFLI uses multimedia technology for teaching and learning activities, incorporating a learning platform with an open forum and a DVD. Each partner develops their share of the lessons which are then adapted to the different languages of the consortium (Catalan, Italian, English and German), and the four sign languages of the countries belonging to the partnership: LSC (Catalan Sign Language), LIS (Italian Sign Language), BSL (British Sign Language) and ÖGS (Austrian Sign Language). So far, the first four lessons have been developed (the topics are: "formal and informal Letter", "CV and cover letter", "press articles" and "how to read a job advert"). DEAFLI includes videos with grammar explanations in the Sign Languages of each of thecountries taking part in the project in order to support the deaf students' comprehension of the contents, as well as interactive exercises (www.deafli.com). Currently, $80 \%$ of deaf people are functional illiterate, in other words, they complete a basic education, but do not reach suitable language proficiency, neither in its oral form nor in its written one, leading to a handicap in social situations due to the fact that written language proficiency is considered an essential tool in advanced societies, since it guarantees fundamental access to information and knowledge and, therefore, helps to develop a better identity and personal autonomy, while it affects social and work integration. Nowadays, accessibility to information and communication in the Deaf community is still far from being a fact, but, from this new perspective, explaining in detail the new strategies that optimize the reading and writing skills of Deaf pupils, it is expected to bring their competences near the levels of their listening counterparts favoring their access to employment, equal opportunities and deterring exclusion.
\end{abstract}

Key words: Deafness and Education, E-Learning.

\section{Introduction}

Deaf people show many difficulties when learning to read and to write, and many deaf people are functional illiterate. In a social context in which the listening channel stands out as a priority to receive information, deaf people constitute a group of population with high unemployment and at risk of exclusion.

In the countries of the consortium, the difficulties to reach a good standard in literacy of deaf people are above a $75 \%$. Few prelocutive deaf people gain access to higher education levels. This affects their access to

Corresponding author: Natalia Pérez Aguado, research fields: deaf community, teaching methods, special education. information, culture, and employability; activate participation in society and equal opportunities.

It is also a handicap regarding their cultural, academic and professional formation and, consequently, access to a qualified job.

All the textbooks and resources for written language teaching-learning are designed for listening students. It is common to forget the specific needs of the deaf students. The didactic resources tend to be written documents, sometimes with phonetic transcriptions, sometimes with an extra audio, most of them without subtitles and without Sign Language. The statistics show that the resources available for teaching deaf persons in most countries are scarcely adapted to deaf people and that the literacy level of 
deaf people is very low compared with that of their equal listeners.

DEAFLI is a European project with number of reference 538750-LLP-1-2013-1-ES-GRUNDTVIG-GM framed inside the program of lifelong learning in the subroutine GRUNDTVIG. GRUNDTVIG is open to any organization working in the field of adult learning. The project started in December, 2014 and it will be finished in December, 2016.

DEAFLI is a 10 lessons course to increase the acquisition of key written language skills for young and adult deaf people, in formation, to improve their education and to ease their access to the working world, in the countries taking part in the project. New materials and resources will be developed for these means. One of the goals of DEAFLI is developing a virtual written language teaching-learning platform for young and adult deaf people of the countries of the consortium. This platform might be used both for presential classes and e-learning. All the lessons will be adapted to the different languages of the consortium (Catalan, Italian, English and German and the four 1 Sign Languages of the partners of consortium: LSC, LIS, BSL and ÖGS). Sign Language will be the vehicular language to facilitate the contents comprehension to deaf DEAFLI users. The project takes the Common European Framework of Reference for Languages as a reference for the contents. The project hopes to help to overcome the difficulties that deaf people face in their access to culture and bring over their linguistic competences to the levels of their listening equals, reducing, therefore, school failure and favoring their access to employment, not exclusion and equal opportunities.

The general target is to develop the reading and writing competences of deaf people and, therefore, to favor their access to education, to vocational training and to culture. To reach this general target resources to promote the development of the written linguistic competences for deaf people are being created as a specific target in order to reduce the existing current literacy failure in this population to favor their access to equal opportunities and avoid exclusion; and, consequently foster their insertion in society. It is hoped that 10 units with their teaching materials will be available in a virtual platform that will allow presential classes and e-learning of the written languages of the countries of the consortium. Every lesson will consist of grammatical explanations and exercises in the Sign Language and the written language of every country of the partnership. The development of the teaching materials is sustained in a visual code, which is the natural route of communication of deaf people, consequently in every lesson basic grammar aspects will be explained (for example the use of capital letters, the use of linkers and verb tenses), by means of the visual input of Sign Language; meeting the demands of adult deaf people. The on-line platform (www.deafli.com) will ease the students who cannot attend the classes to access the didactic units. In the platform there will also be video files with grammar explanations in Sign Language.

It is also a target of the project to spread the final products so that, in a near future DEAFLI could be used by as many beneficiaries as possible and continue the development of the project beyond the year 2017. The final product might be applied to other "target groups", and adapted to other European written languages and Sign Languages in a future.

\section{Materials and Methods}

\subsection{The Importance of Written Language in the Current Society}

The concept of "writing" has suffered considerable changes along history, since, from a traditional perspective, it was considered to be the direct transfer from oral language to a few graphic signs, although, in the last decade the definition has been rectified and written language is described as a different language, independent from oral language (Halliday, 1985) and object of sociocultural knowledge. According to an increasing educational quality and, to what is 
established in the Constitutional Education Law $2 / 2006$, in our current society there is a will to try to ease effective access to reading and writing, one of the learning's keys that competence reveals in linguistic communication.

The mastery of written language in advanced societies is considered to be an essential sociocultural tool since it is a fundamental instrument to access information and knowledge, allowing to gain access to a better identity and personal autonomy while it affects social and work integration.

At present, the person who does not have access to written language is considered to be an uncultured and illiterate person, who loses a lot of information from the surrounding world (Szwed, 1979; Wells, 1987). Therefore this knowledge must be promoted since early ages.

Writing is, consequently, the most powerful cognitive tool to gain access to knowledge and to have numerous and significant opportunities to learn (Ruiz, 2009), by what it is considered to be one of the fundamental props of educational targets. Also, in people who present communication and language handicaps, such as deaf people, the written text becomes one of the most effective means to receive information and to gain access to knowledge (Domínguez, 2003).

\subsection{Sign Language. Lingua for Learning}

Listeners, since birth, are immersed in the oral world without adults' premeditation (Fernández-Viader, 1992; Wells, 1988; Pertusa, 2002). Therefore, when they begin school they already have some knowledge about written language and reach, along their schooling, suitable and functional reading and writting skills.

Nevertheless, plenty are the researches that state the difficulties that deaf children show regarding written language (Asensio, 1989; Conrad, 1979; Marschark, 1993; Paul, 2001; Quigley and Paul, 1984; Wood and cabbage. 1986, Fernández-Viader and Pertusa, 2005), since, most of them, begin to learn how to read and write without having reached basic comprehension levels of linguistic and metalinguistic production. Consequently, usually, the process of learning written language and oral language takes place simultaneously.

Nowadays, $90 \%$ of deaf children have listening parents (Pertusa, 2002), therefore, heterogeneous dyads are more common, and, due to the fact that, most deaf children do not acquire a mother, natural and spontaneous tongue, the absence of communication reverberates in the general linguistic competence; the general knowledge on the world; the previous experiences with the written and the motivation towards written language causing big difficulties in written language acquisition and obtaining shallows results in the area.

On the other hand, if deaf children gain access to written language from a bilingual option and, therefore, they have since early ages a language, Sign Language in this case, not only they acquire a linguistic competence in Sign Language that leads to a better access to written language, but also, the experiences of interaction and communication will be richer and more varied, as they will have a better access to information and knowledge and a wider experience with the written.

Comparative studies that show the academic results of deaf children educated in oral language monolingual approaches, with their equal bilingual ones educated in Sign Language, have shown favorable results towards the bilingual ones (Heiling, 1994, 1999), since they have a basic language to use as a base while learning written language.Also, authors such as Andrews (1994) and Neal (1995) have corroborated that Sign Language promotes a semantic and conceptual support that eases the comprehension of written texts, and even, the competence in Sign Language can allow both the professorship and the pupils, to carry out activities that relate and compare both languages. A pilot study in Barcelona 
(Fernández-Viader and Pertusa, 1994) verified how adults and educators would resort systematically to Sign Language and fingerspelling to carry out metalinguistic reflections on the use of the language and writing rules with children.

Different authors (Caselli and Pagliari, 1991; Fernández-Viader, 1994，1996; Hoffmeister, 1990; Livingston, 1997) defend that deaf children learn initially use the language of their community, Sign Language and, later gain access to oral and written language, since it is essential that they are immersed in a suitable linguistic environment and have a communication system shared among the speakers for the mastery of written language (Fernández-Viader, 1993, 1994; Fernández Viader and Pertusa, 2005).

\subsection{Deafness and Written Language: The State of the Art}

The studies concerning the writing of deaf people are distributed in two big groups, depending on the priority targets that they chase: on the one hand, researchers with a descriptive approach and, on the other hand, those with an argumentative approach (Fernández-Viader and Pertusa, 1996).

First of all, the researches with a descriptive approach are those whose target is to detect, to admit and to classify the errors carried out by deaf subjects in their written productions, compared to their listening equals, not only at a lexical level but at a morphosyntactic and semantical level.

Regarding lexical errors, deaf pupils begin learning written language with lower vocabulary levels than those of their listening equals, (King and Quigley, 1985, Myklebust, 1960; Ivimey, 1976, Paul, 1984; Fletxer and others, 1993); Also, they use more content words, calls of semantic class (nouns, verbs and some adjectives), than function words of syntactic class (articles, auxiliaries, prepositions and conjunctions) (Simmons, 1962; Taylor, 1969).

Regarding general morphosyntactic errors, deaf pupils present shorter, simple, rigid stereotyped sentences when compared with their listening equals, (Heider and Heider, 1941; Simmons, 1962; Wollman, 1964; Cooper and Rosenstein, 1966; Ivimey, 1976; Taescher, 1989; Taescher, Devescovi and Volterra, 1988; Fletxer and others, 1993). Also, they show difficulties in the comprehension and production of the syntactic structures of the sentence (Quigley and Paul, 1984; Grain, 1998; Ivimey, 1976), consequetnly, do not make use, or make a bad use of the series of grammatical keys. The researches of Quigley, Wilbur and Montanelli (1976) determined that the syntactic skills of the average 18-year-old deaf people are lower than those of 8-year-old listeners. Therefore the easiest syntactic structures are the direct, affirmative and active ones; being the most complex, successively, reported speech sentences, conjunction, relative and passive sentences (Taylor, 1969; Quigley and Power, 1977; Taescher, 1989, Robbins and Hatcher, 1981). Finally deaf subjects possess specific and concrete skills to express themselves in writing due to the communicative experiences based on the reception and visual perception, and not to a deficit of cognitive type (Lacerte, 1989). Some studies state that in the writings of many deaf people its meaning can be extracted more easily if one resorts to Sign Language rules (Klyle, 1985).

Regarding semantic errors, the low vocabulary level provokes that the possibilities of knowledge of the key words of a text are fewer. Several researchers, in fact, support the idea that deaf people usually deduce the content of the text from the words that turn out to be more familiar to them, independently of the importance that they could have regarding the main ideas (Grain, 1998). Grain and Ramspott (1996) affirm that deaf subjects use the model called "model of the double route", since, for the deduction of the meaning, they present a major tendency to use the lexical or direct route instead of the phonological route, therefore they identify the words from diverse graphic features such as the length or the shapeof the letters, therefore it induces the deaf person to 
confusion, for example in the terms "abundancia y ambulancia. Also, deaf subjects present difficulties in the semic relationships (antonyms, synonymous, metaphors and polysemies) Gutiérrez, 2012.

Secondly, the researchers with an argumentative approach try to know the possible causes or motives of the errors that deaf people present in their written language and even to contribute to the decrease or suppression of the above mentioned mistakes with concrete didactic contributions. At present, other authors, such as Domínguez (2003) or Fernández-Viader and Pertusa (2005) try to look for new arguments why deaf pupils reach low reading and writing levels and raise some recommendations to improve the results of teaching-learning.

Although we can find several researches concerning the mastery of written language for deaf subjects, these studies are scarce and insufficient and, in general, they focus on the handwriting instruction in early ages (Pertusa, 2002; Fernández-Viader, 2005), as didactic proposals focused in the education of the Catalan written language to Deaf adults do not exist yet, since the project DEAL (2008) and DEAL TOI (2012) proposed a course of English written language for written business communication.

\section{Methodology}

DEAFLI started with the study of the state of the art on Deaf People's literacy in the countries of the consortium. This was carried out by means of bibliographical studies and interviews to deaf people (young people and adults) to get to know how their education had been carried out and what where their needs regarding written language teaching-learning. Since the beginning of the project, experimental courses of written language teaching to deaf persons have been carried out, from which we are obtaining information about the best optimizing resources and didactic strategies for teaching this population (1) and we have obtained information referred to the most common grammatical, morphologic and syntactical errors in Deaf people's writing. This has allowed us to have a starting point about the contents to be used at the different units to be developed. All the explanations of the course are being adapted to the different sign languages of the consortium, to guarantee that the information contained in the course could be understood by the users and that the developed material is useful for e-learning. In Fig. 1, Fig. 2, Fig. 3 and Fig. 4 examples of the DEAFLI platform.

The DEAFLI project proposes to develop 10 thematic units sustained in an introductory reading with grammatical contents and exercises related to the subject-matter. Bearing in mind that one of the targets of the project is to help Deaf people with their work integration, the chosen topics were related to working environment topics. The first chosen topics were: Explanation of formal and informal letters, The CV and the Cover Letter, Press articles, How to read a Job Advert.

Currently, new thematic units are being developed: explanation of the sociolinguistic situation of the written languages included in the project, introduction to basic spelling and a third unit referred to vocabulary related with jobs and working environment. In parallel there grammatical units that will be tackled in a transversal way in the different thematic units are under development. The grammar and syntactic contents developed so far are: articles (also related to genre and number), the noun, verb tenses (the present and the next past), affirmative sentences, negative sentences, the adjective, pronouns, interrogative sentences, interrogative particles and the subject.

At present new thematic and grammar contents are being developed and the contents are being adapted to the written languages and the sign languages of the consortium developed so far.

All the texts, grammar explanations, exercises and videos with the explanations in Sign Languages are going to be uploaded to the platform of the DEAFLI Course. 


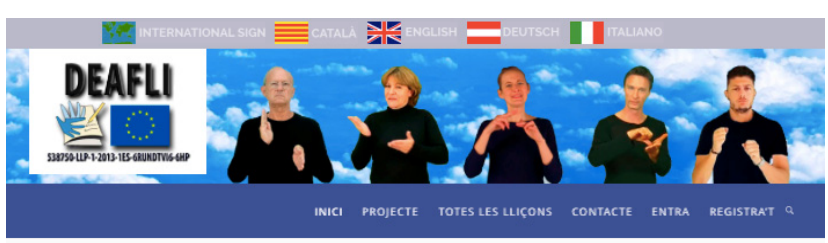

Benvinguts al projecte DEAFLI

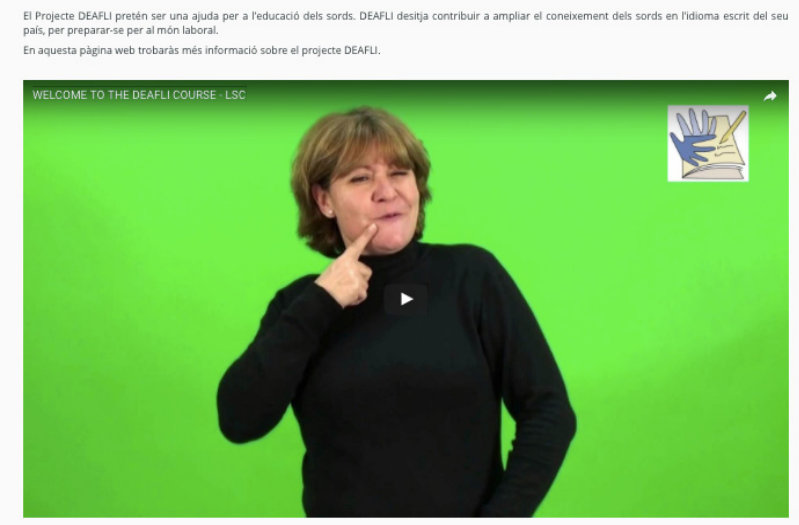

Projecte

Lliçons
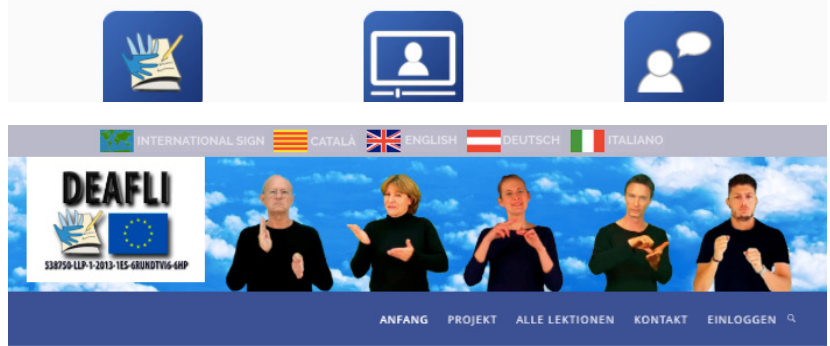

Willkommen beim Projekt DEAFLI

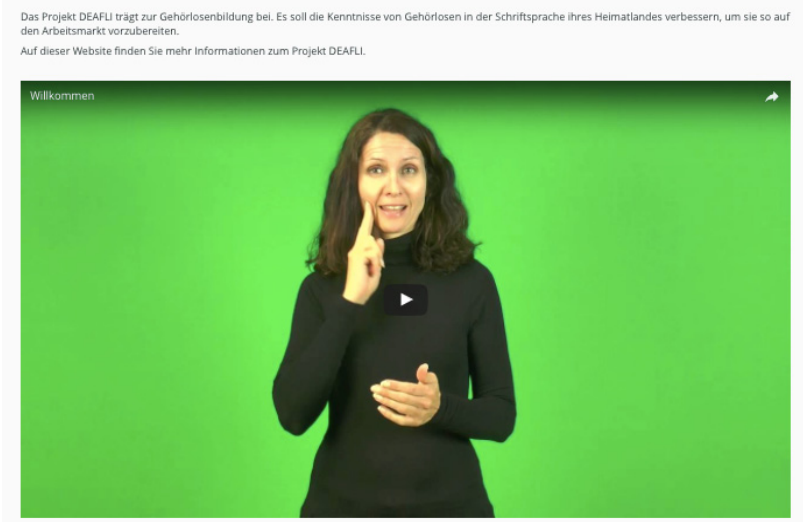

Projekt

Zu den Lektionen

Kontakt
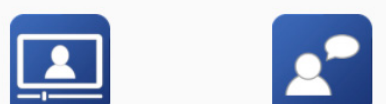

Fig. 1 Catalan Sign Language (LSC); Fig. 2: English Sign Language (BSL); Fig. 3: Austrian Sign Language (ÖGS); Fig. 4: Italian Sign Language (LIS).

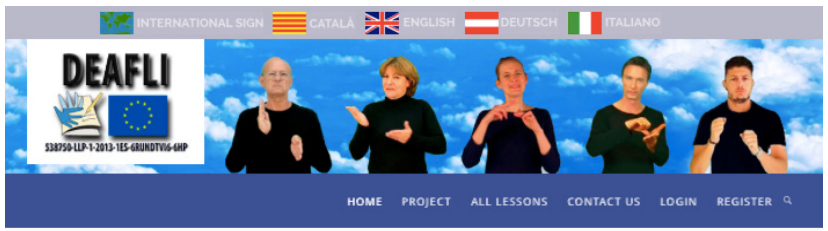

Welcome to the DEAFLI project

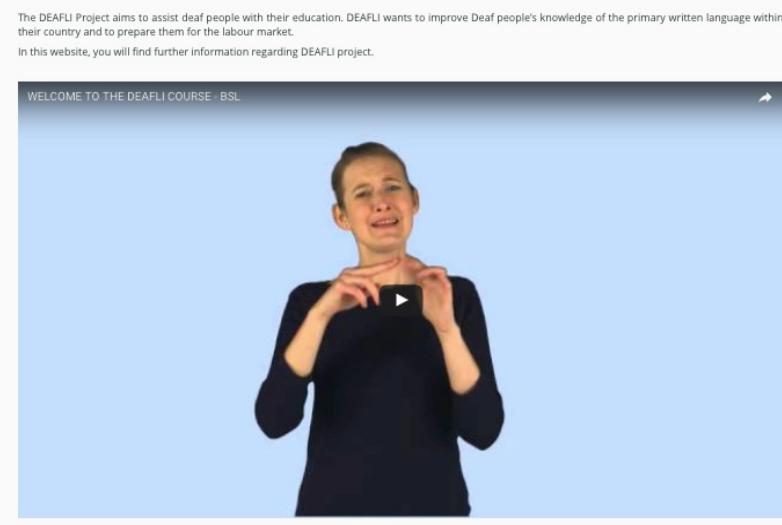

Project

Lessons

Contact
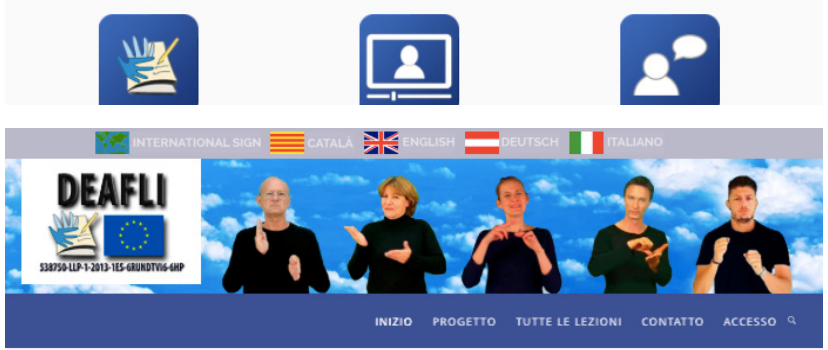

Benvenuti al progetto DEAFLI

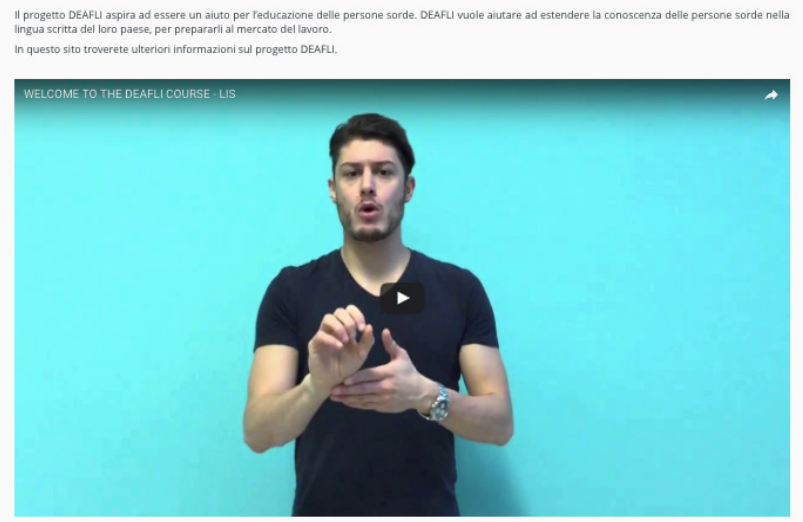

Progetto

Lezioni

Contatto
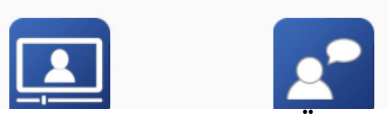


\section{Results and Discussion}

Currently, we have the report about the state of the art of Deaf people's literacy in the countries the consortium. Immediately after the results obtained in the study of the state of the art and in the experimental courses we have also written down a report of the most common errors in the deaf people's writing.

So far, 7 thematic units have been developed (Explanation of formal and informal letters, The CV and the Cover Letter, Press articles, How to read a Job Advert, explanation of the sociolinguistic situation of the written languages included in the project, introduction to basic spelling and a third unit referred to vocabulary related with jobs and working environment). Some of these units have already been translated and adapted to all the written languages and the sign languages of the consortium and others are being adapted and translated at present. Several units have also developed with the explanation of diverse grammar and syntactic contents (articles (also related to genre and number), the noun, verb tenses (the present and the next past), affirmative sentences, negative sentences, the adjective, pronouns, interrogative sentences, interrogative particles and the subject). Both the thematic units and the units with the grammar and syntactic explanations are going to be extended along the development of the project.

\section{Conclusions}

As it has already been mentioned above, the materials developed so far for written language teaching-learning hardly ever take into account the needs and characteristics of the deaf population. DEAFLI tries to develop new didactic resources for this mean improving teaching intervention that deaf people receive at a European level and sensitizing the people in charge of the educational politics of the European countries about the educational needs of this population, thus, helping to compare the quality of their formation with that of their equal listeners.
This material can be used by teachers dedicated to deaf people's education and by adult deaf people with a low literacy level that want to improve their linguistic skills autonomously. It will also be useful for listeners with cognitive disabilities and/or communication difficulties and a low literacy level and as a resource to be used by professionals who instruct people with cognitive disabilities and with learning handicaps that could be favored by the use of sign language as an instruction tool. This project can also be an effective tool to favor the didactic and cooperative research among equals and to encourage young researchers to get instructed in this line of action and research by means of the preparation of Ph.D. theses and master's degrees, focused on the education of written language to the deaf population.

The DEAFLI course will offer resources that will be able to get adapted to the written languages and sign languages of other European countries. It will also provide all the interested parts, the chance to add new thematic, grammar and morphosyntactic contents.

\section{References}

[1] Akamatsu, C. \& Armour, V. (1987). Developing Literacy in Deaf children trough analyzing Sign Language. American Annals of the deaf, 132-145.

[2] Alegría, J. \& Domínguez, A.B. (en prensa). Los alumnos sordos y la lengua escrita. Revista Latinoamericana de Educación Inclusiva. (www.rinace.net/rlei)

[3] Alonso, P. (1999). Comprensión y producción de textos por parte de niños sordos escolarizados en un centro bilingüe. En A. B. Domínguez y C. Velasco (coord.). Lenguaje escrito y sordera. Enfoques teóricos $y$ derivaciones prácticas. Salamanca: Publicaciones Universidad Pontificia de Salamanca.

[4] Anderson, J. (1994). Second Language Literacy in Deaf Students. En I. Ahlgren y K. Hyltenstam (Eds.) Bilinguism in Deaf Education. Germany: Signum. Banks, J., Gray, C. \& Fyfe, R. (1990). The written recall of printed stories by severely deaf children. British journal of education psychology, 60, 192-206.

[5] Bishop, D. (1983). Comprehension of English syntax by profoundly deaf children. Journal of Child Psychology and Psychiatry, 24, 415-434.

[6] Caselli, C., Masoni, P., Ursono, M., Pace, C. \& Skliar, C. (1992). La competencia narrativa en los niños sordos: 
estrategias morfosintácticas, de coherencia y cohesión de textos. Inédito.

[7] Charrow, V. R. (1981). The written English of deaf adolescents. En Writing: the nature, development and teaching of written communication, M. F. WHITEMAN (Ed.), N. J.Hillsdale. Lawrence Erlbaum Associates, 179-187.

[8] 8Pertusa (2002). La escritura en el niño sordo y estrategias de la maestra. Barcelona: Universidad de Barcelona.

[9] 10Conrad, R. (1979). The deaf school child: Language and cognitive function. Londres: Harper and Row.

[10] Cooper, R. \& Rosenstein, J. (1966). Language acquisition of deaf children. Volta Rev., 68,58-67.

[11] Domínguez, A. B. (2001): La enseñanza del lenguaje escrito a niños sordos escolarizados en un centro bilingüe: papel de la lengua de signos y la palabra complementada, pp. 33-44. 1 $\square^{\mathrm{s}} \mathrm{J}$ ornadasRegionales de Atención Educativa al alumnado con Deficiencia Auditiva. Murcia.

[12] Dominguez, A.B. \& Alonso, P. (2004). La enseñanza de los alumnos sordos hoy. Perspectivas y respuestas educativas. Málaga: Aljibe.

[13] Dominguez, A.B. \& Velasco, C. (1999). Lenguaje escrito y sordera. Enfoques teóricos y derivaciones prácticas. Salamanca: Ed. Universidad Pontificia.

[14] Fabretti, D., Volterra, V. \& Pontecorvo, C. (1998). Written Language Abilities in Deaf Italians. Journal of Deaf Studies and Deaf Education. Vol.3, 3, 231-244.

[15] Fernández-Viader, M. P. (1994b). Dificultades del lenguaje oral. En S. Molina (eds.), 24 Bases psicopedagógicas de la Educación Especial. Zaragoza: Marfil.

[16] Fernández-Viader, M.P. (Ed.) (2017). Deaf Literacy: From classroom teaching to the Deafli Course. Barcelona: Illescat.

[17] Fernández-Viader, M. P., Pertusa, E. \& Vinardell, M. (1999). Importancia de las estrategias de la maestra sorda en el proceso de enseñanza -aprendizaje de la lengua escrita. En C. Sckliar (Eds.) Actualidad de la Educación Bilingüe para sordos, 2, 47-59. Porto Alegre: Ed. Mediaçao.
[18] Fernández-Viader, M. P. \& Pertusa, E. (1995ª). La escritura de los adolescentes sordos. I Encuentro Internacional sobre adquisición de las lenguas del estado.

[19] (1996b): Reflexiones sobre la escritura y alfabetización de los niños sordos. Revista de Logopedia, Foniatría y Audiología, vol. XVI, n², pp. 79-85.

[20] (1999): Representación fonológica, aprendizaje de la escritura y sordera. Revista de Logopedia, Foniatría y Audiología, vol. XIX, ${ }^{\circ} 1$, pp. 2-11.

[21] (2005). El valor de la mirada: sordera y educación. Barcelona: Publicacions i Edicions de la Universitat de Barcelona.

[22] Pérez Aguado \& Fernández-Viader, (2015). Deaf adults' literacy in Catalonia: Deaf teacher strategies. EDULEARN15 Proceedings, pp. 2213-2221.

[23] (2016a). Deaf teacher strategies in the classroom. EDULEARN16 Proceedings, pp. 1691-1701.

[24] (2016b). Teaching how to write in Catalan: Strategies for deaf students. ICERI2016 Proceedings, pp. 5371-5381.

[25] (2017a). Una innovadora página web para la instrucción de lengua escrita a Sordos: el proyecto DEAFLI, Faro del Silencio (en prensa).

[26] (2017b). Los recursos visuales como elementos ineludibles en la enseñanza a Sordos: propuestas de intervención educativa, Faro del Silencio (en prensa).

[27] (2017c). The importance of visual strategies with Deaf pupils: cases analysis. INTED2017 Proceedings.

[28] (2017d). Bibliographic references. En Fernández-Viader (Ed.) Deaf Literacy: From classroom teaching to the Deafli Course. Barcelona: Fundació Illescat, pp. 154-226.

[29] Pérez Aguado, Fernández-Viader, M.P. \& Dolza, E. (2017). State of the art of the literacy of Deaf people in Austria, Catalonia, Italy and the UK. En Férnandez-Viader (Ed.) Deaf Literacy: From classroom teaching to the Deafli Course. Barcelona: Fundació Illescat, pp. 74-90.

[30] Pérez Aguado, Fernández-Viader, M.P. \& Fernández, A. (2017). Teaching strategies, from classroom teaching to the Deafli course. En Férnandez-Viader (Ed.) Deaf Literacy: From classroom teaching to the Deafli Course. Barcelona: Fundacií Illescat, pp. 141-147. 